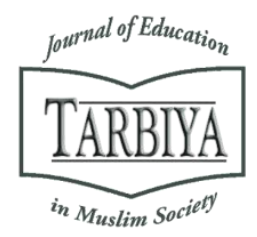

Available online at TARBIYA: Journal of Education in Muslim Society Website:

http://journal.uinjkt.ac.id/index.php/tarbiya

TARBIYA: Journal of Education in Muslim Society, 7(2), 2020, 158-166

\title{
PRINTED-BOOK READING HABITS OF PRE-SERVICE SCIENCE-TEACHER STUDENTS
}

\author{
Imam Bachtiar \\ Universitas Mataram, Mataram, NTB, Indonesia \\ E-mail: imambachtiar@unram.ac.id
}

Received: $15^{\text {th }}$ August 2020; Revised: $14^{\text {th }}$ November 2020; Accepted: $28^{\text {th }}$ December 2020

\begin{abstract}
Many studies reported that reading could improve academic achievements, critical thinking skills, confidence, social behaviour, and all students' characters to get a better job and a better life. However, many students are potentially disrupted by social media interactions in the Disruption Era that affected their reading habits. The present study aimed to explore the reading habits of students in the printed textbook. The study was carried out in 2019, involving 469 students from three study programs of the Department of Mathematics and Science Education, i.e. Biology Education, Chemistry Education, and Physics Education. Data were collected using questionnaires in a convenience sampling method, with a sample of approximately $70 \%$ of the population. Results show that $81 \%$ of students read printed textbooks for two hours or less per day, and $53 \%$ spend less than one hour. There are a few students, however, who read textbooks more than four hours per day. Students' visit to the library is mostly (35\%) 3-4 times per year and $>5$ times per year (33\%). Reading for leisure is not very popular among students. Multiple regression models showed that students' science textbooks, students' interest in information technology books, the number of literature read, and the number of bought-books significantly determine the duration of students' reading time. Potential methods to improve students' reading habits are discussed.
\end{abstract}

Keywords: reading; pre-service; science; teacher; textbooks

\section{Abstrak}

Salah satu bidang Tehnologi pembelajara adalah pemanfaatan teknologi informasi sebagai media pembelajaran. Hal tersebut selaras dengan perkembangan abad 4,0. Kemampuan siswa dalam menggunakan dan memanfaatkan computer (Komputer Literasi) menjadi isu yang menarik saat ini. Komputer literasi menjadi bagian dari teknologi pembelajaran. Tujuan dari penelitian ini untuk menganalisis implementasi penggunaan laptop Mobile dalam aktivitas belajar di kelas dan bagaimana respon siswa dalam penggunaan laptop Mobile di kelas. Penelitian ini dilakukan dengan survey. Sedangkan metode pengumpulan datanya dilakukan dengan cara wawancara, observasi, dan dokumentasi. Subjek penelitian ini adalah siswa kelas VII, VIII, dan VIII sejumlah 312 anak. Analisis penelitian ini dilakukan dengan cara mengumpulkan data, mereduksi, menganalisis, dan membuat kesimpulan. Hasil penelitian ini menunjukkan bahwa implementasi penggunaan laptop mobile dilakukan saat proses belajar mengajar dilakukan dengan cara 1) semua materi dimasukkan dalam laptop mobile, 2) semua siswa mendapatkan hak akses untuk menggunakannya, dan 3) aktivitas belajar sudah didesain dalam laptop mobile. Sedangkan respon siswa dalam menggunakan mobile laptop menunjukkan 1) tingkat kepuasaan dalam menggunakan laptop mobile, 2) tingkat kemanfaatan dalam menggunakan laptop mobile, dan 3) tingkat tanggungjawab dalam merawat laptop mobile pada angka rerata yang paling tinggi pada lilihan stuju dan sangat setuju.

Kata kunci: teknologi pembelajaran; laptop mobile; media pembelajaran; aktivitas belajar

How to Cite: Bachtiar, I. (2020). Printed-Book Reading Habits of Pre-Service Science-Teacher Students. TARBIYA: Journal of Education in Muslim Society, 7(2), 158-166. doi:10.15408/tjems.v7i2.16888.

Permalink/DOI: http://dx.doi.org/10.15408/tjems.v7i2.16888 


\section{Introduction}

Reading textbooks and journals, either in printed or electronic materials, should be the university students' most activities. Many studies showed that students reading practices improve student's academic achievement and critical thinking skills (Sappington et al., 2002; Bharuthram, 2012; Balan et al., 2019). Girls, high social-economics status (SES) students, and students in high academic records have been reported to have better performance in both reading enjoyment and reading comprehension (Rogiers et al., 2020). In the Disruption Era, where social life changes rapidly due to technology development, many students spend more and more time on social media. Reading printed materials as a university student's tradition may be disrupted as social media use increases in recent years.

Students' intensive use of social networking media is parallel with students' shift preference to electronic reading materials. More than $70 \%$ of students prefer digital to printed reading materials (Manalu, 2019). Another study in a university in Central Indonesia suggests that students' preferences on electronic reading materials are considerably high (34-40\%), although more students have a preference to read printed reading materials (Kurniawan et al., 2018). The shift from print to digital reading materials is not only encouraging but also challenging. Personal observation suggests that some students think that reading a printed textbook is no longer an obligation. They can substitute textbooks for any digital information they found on the internet. They even only rely on Wikipedia or any unauthorized science readings materials available on Google searching machine.

Reading materials available in Google Scholar are not scholarly selected, as it lacks quality control (Halevi et al., 2016). There are non-peer-reviewed science papers indexed in Google Scholar (Halevi et al., 2016; MartinMartin et al., 2017 \& 2018). Several studies show that many students have difficulties identifying fake news in social media (Leeder, 2019; Syam \& Nurahmi, 2020). These studies could also indicate that many students have trouble distinguishing between scholarly (peerreviewed) and non-scholarly reading materials. When students rely on non-scholarly reading materials, they may develop inappropriate scientific knowledge, skills, and attitudes.

There are at least two reasons that students can easily slip into non-scholar reading materials when they rely on non-printed reading materials. Firstly, many students lack English reading proficiency, while most scholarly papers are available in the English language. Furthermore, many students do not have free access to scholarly scientific papers. When students rely primarily on Bahasa Indonesia's reading materials on the internet, they are easily trapped in fakescience reading materials on blogs or open-access predatory journals. Students could check the scholar status of the journal they read in the Sinta, an Indonesian index for national scientific journals. However, such careful action would be a minority case, as many students may not be aware of this issue. For example, biomedical students' awareness of predatory journals was reported very low, only 7\% in Jordan (AlRyalat et al. 2019), $9 \%$ in Saudi Arabia, and $8 \%$ in New Zealand (Alamri et al., 2020).

The present study is to describe the reading habits of pre-service science-teacher on printed textbooks. Reading habits consist of times spent in reading, number of book-reading, and reading frequency. In the present study, reading habit is studied mainly on time spent reading or the duration of reading time. The study is critical to ensure that the future science teacher has a comprehensive understanding of the basic 
concepts and principles of sciences that they will teach shortly.

\section{Method}

The present study was carried out in the Department of Mathematics and Science Education (DMSE), Faculty of Teacher Training and Education of a university in Central Indonesia. The DMSE consists of four study programs, i.e. Biology Education (BE), Chemistry Education (CE), Physics Education (PE), and Mathematics Education (ME). This study did not involve students from ME due to limited time and resources.

Data on student's reading habits on printed textbooks were collected using validated questionnaires. Several senior students $\left(5^{\text {th }}\right.$ semester) in three to five went to targeted classrooms and asked students in the classroom to anonymously answer the printed questionnaires. The questionnaires would take about 5 minutes to fill in.

There were 469 students as a sample of the study. Student samples were non-randomly selected in the $\mathrm{BE}, \mathrm{CE}$, and PE study programs, using a convenience sampling method. Students in all classes and batch (cohorts) were asked to participate in the study. Students willing to participate in the study became the sample of the study. Although they were not randomly selected, samples were considered to represent the population in many ways since their proportion is high, $>70 \%$ of the population.

The samples consisted of mostly female students $(86 \%)$ since female students predominate the department's student population. In this regard, the sex ratio of the samples represented the sex ratio of the population. Students of the cohorts 2014 were least sampled (Table 1) since the survey was conducted when most students of the cohort were off-campus for teaching practice at schools.
Collected data in the questionnaires were: a) students' reading hours (daily in the last week); b) book subjects that mostly read (in the last semester); c) number literature-book read (in the last year); d) number of library visits (in the last year); e) number of books borrowed (in the last year); f) number of books bought (in the last year); g) the number of book-collection.

Table 1. Sample distribution among study programs, cohorts, and sexes

\begin{tabular}{lllllll}
\hline \multirow{2}{*}{$\begin{array}{l}\text { Study } \\
\text { Program }\end{array}$} & \multicolumn{2}{l}{ Cohorts } & & & \multicolumn{3}{l}{ Sex } \\
\cline { 2 - 7 } & 2014 & 2015 & 2016 & 2017 & $\mathrm{M}$ & $\mathrm{F}$ \\
\hline BE* $^{*}$ & 0 & 44 & 69 & 62 & 28 & 148 \\
\hline $\mathrm{CE}^{* *}$ & 39 & 23 & 43 & 74 & 23 & 154 \\
\hline PE $^{* * *}$ & 0 & 59 & 32 & 24 & 15 & 100 \\
\hline${ }^{*} \mathrm{BE}=$ Biology & Education, & ${ }^{* *} \mathrm{CE}=$ Chemistry & Education, \\
$* * * \mathrm{PE}=$ Physics Education & & & & &
\end{tabular}

Univariate data were analyzed using a Chisquare and Analysis of variances (ANOVA); Chisquare was applied to determine the association between two variables of interest. ANOVA was applied to test differences among univariate variables, including the number of book collections among three study programs.

Multivariate data collected in the present study were analyzed using a multiple regression model to explore essential variables determining the duration of reading time (DRT). There were 12 variables tested in the multiple regression analysis, i.e. student's rank of the textbook (RTB), the rank of history (biography) book (RHB), the rank of information technology book (RIT), the rank of religion book (RRL), the rank of self-development book (RSD), number of book collection (NBC), number of library visit (NLV), number of literature read (NLR), number of borrowed books (NBoB), number of bought books $(\mathrm{NBuB})$ and students' sex $(\mathrm{Sex})$. As these variables have various scales, all variables were standardized using their totals before multiple regression analyses were applied. The multiple regression analysis was performed using the software JMP® Pro version 13.0.0 (2016). 


\section{Results and Discussion}

Many students (53.32\%) spent minimum hours ( $<1$ hour) per day in the reading textbook. Most students (80.94\%) spend less than 3 hours/day reading the printed textbook. This low reading activity was found equally among students from the three study programs (Figure 1). Proportion of students with maximum time (>4 hours/day) were $6.21 \%$ (CE), 7.83\% (PE) and $10.86 \%(\mathrm{BE})$. These indicated that textbook reading is not popular reading activity among pre-service science-education students.

The duration of students' textbook-reading was independent of their study programs.

Students of the three study programs have about the same proportions in the four reading hours categories (Chi-square, $\chi^{2}=5.5319, \mathrm{df}=4$, $\mathrm{N}=467, \mathrm{P}>0.05)$. Most of them read textbooks in 1-2 hours per day.

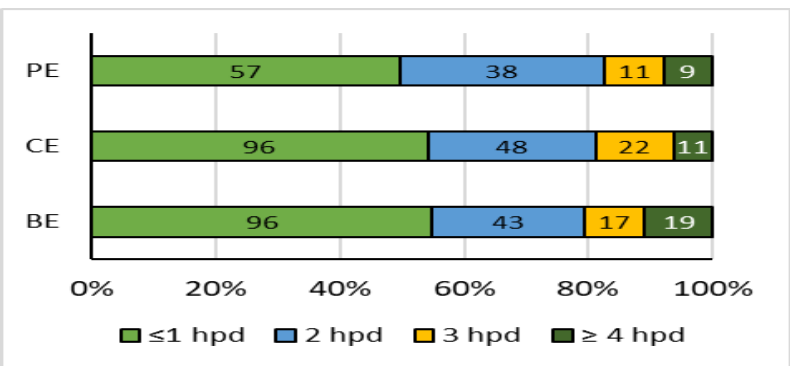

Figure 1. Time spent on textbook-reading of science education students (hpd, hour per day) among three study programs

The longitudinal comparison showed that the time spent on textbook reading on students from the $2^{\text {nd }}$ semester to the $8^{\text {th }}$ semester was very consistent (Figure 2). About $80 \%$ of students read textbooks in two hours or less per day. However, no students in the 8th semester (S-8) read textbooks more than three hours per day. Besides the number of samples on this cohort, which was low, they likely did not have any more lectures to attend. It means there was no more extended preparation for their exam.
There was no association between student cohorts (semester) and their time spent on textbook-reading. Regardless of their cohorts, most students spent two hours or less for textbook reading every day (Chi-square, $\left.\chi^{2}=9.1386, \mathrm{df}=6, \mathrm{~N}=467, \mathrm{P}>0.05\right)$.

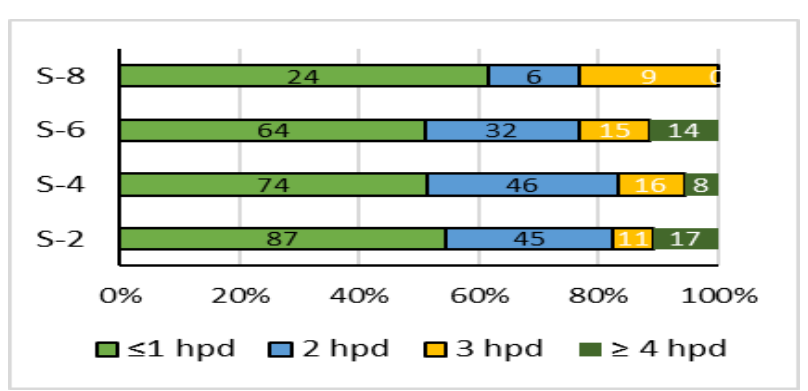

Figure 2. Time spent on textbook-reading of science education students (hpd, hour per day) among four students' cohorts

Students of the three study programs read history or biography books more frequently than science textbooks. The first two books were ranked the highest. The frequency of students reading science textbooks was about the same as religion books. The frequency of reading the two books was, however, ranked only 3 out of 5 . It is also interesting that most students in $\mathrm{BE}$ and $\mathrm{PE}$ study programs ranked literature as one of the books they most frequently read (Table 2), along with books on history and information technology subjects. Students of CE have slightly different favourites in book subjects.

Table 2. Mode ranking of book-subjects read by students

\begin{tabular}{llll}
\hline Type of Books & BE & CE & PE \\
\hline Textbook & 3 & 3 & 3 \\
\hline History/Biography & 1 & 1 & 1 \\
\hline Information Technology & 1 & 2 & 1 \\
\hline Literature & 1 & 3 & 1 \\
\hline Development & 2 & 2 & 1 \\
\hline Religion & 3 & 3 & 3 \\
\hline
\end{tabular}

Literature reading may be an indicator for pleasure reading. Although literature books had considerably high rank, pleasure reading is not 
famous for many students. Literature was among the least frequently book read. The number of literature reading per year was mainly only one or two books (Figure 3). It means that student's enjoyment in book reading is very low. This low reading practice is also supported because $21.67 \%$ of students never read any literature books, and $56.44 \%$ of students read less than two book titles in the last year.

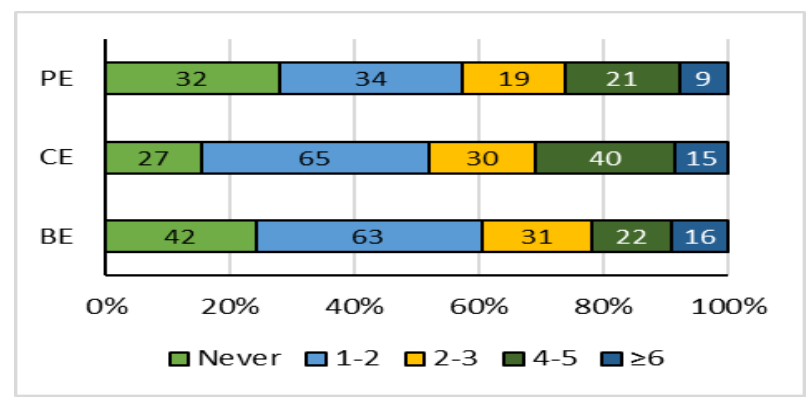

Figure 3. Number of literature-book title read by students in the last year

The distribution of students' literature-book reading was also independent of study programs. Students of the three departments have about the same proportions in the four literature-book reading categories (Chi-square, $\chi^{2}=12.1853$, $\mathrm{df}=4, \mathrm{~N}=467, \mathrm{P}>0.05)$. There was no association between students' study programs and their literature-book reading activities.

The number of books in students' private collection varied greatly, with a range between 0 to 75 books. The averages of student's book collection $( \pm \mathrm{SD})$ in BE, CE, and PE study programs were $11.51 \pm 14.03,8.58 \pm 8.64$, $9.72 \pm 11.70$ books, respectively (Figure 4). The broad standard deviation of student's book collection may be related to their widely spread social-economic status.

The number of book collections was not significantly different among the three study programs. Analysis of variances (ANOVA) showed that differences on the three averages were not significant $(\mathrm{F}=1.3325, \mathrm{df}=2,465 ; \mathrm{P}>$ $0.05)$. All three student groups have about the same averages of book collections.

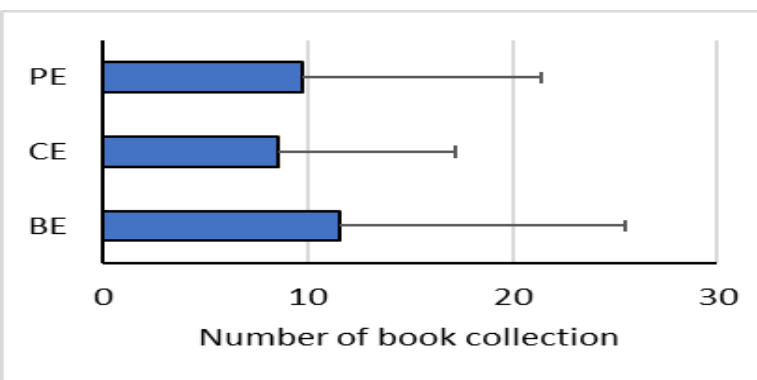

Figure 4. The average number of books in student's collections. Error bars indicate $1 \mathrm{SD}$

Stepwise multiple regression model revealed that four essential variables in determining the duration of reading time (DRT) were student's ranking in textbook reading (RTB), student's ranking of information technology book (RIT), number of literature reading (NLR), and number of bought books (NBuB). The regression model was found significant in Anova $(\mathrm{F}=14.819 ; \mathrm{df}=4$, 455; $\mathrm{P}<0.01$ ) as presented in Table 3 and Table 4. The determination coefficient $\left(R^{2}\right)$ of the multiple regression model was $11.54 \%$.

The present study showed that most students have low reading practice on printed reading materials. This finding is similar to students of English Departments in five state universities in East Java Province (Indonesia) that $56 \%$ of them read less than 2 hours per day (Iftanti, 2012). The low reading practice has also been reported in many developing countries, such as South African universities (Balfour, 2002). Furthermore, a study in Malaysian polytechnic students reported that $76.5 \%$ of students spent less than two hours daily reading books (Annamalai \& Muniandy, 2013).

However, in a developed country, poor reading practice on educational materials was also reported at a university in the United Kingdom (UK). At this university, the average student's length reading time was about 14.05 hours per week (St Claire-Thomson et al., 2018). This data is about the same as in the present study, where $81 \%$ of students read textbooks for two hours or less per day. 
Table 3. Analysis of Variance

\begin{tabular}{lllll}
\hline Source & DF & SS & MS & F Ratio \\
\hline Model & 4 & 53.409 & 13.352 & 14.8190 \\
\hline Error & 455 & 409.968 & 0.901 & Prob $>$ F \\
\hline C. Total & 459 & 463.378 & & $<.0001^{*}$
\end{tabular}

Table 4. Parameter Estimates

\begin{tabular}{lllll}
\hline Term & $\begin{array}{l}\text { Estimat } \\
\mathbf{e}\end{array}$ & SE & $\begin{array}{l}\mathbf{t} \\
\text { Ratio }\end{array}$ & Prob>|t| \\
\hline Intercept & 0.0037 & 0.044 & 0.08 & 0.9332 \\
\hline STD RTB & 0.1338 & 0.048 & 2.80 & $0.0053^{*}$ \\
\hline STD RTIB & 0.1236 & 0.047 & 2.64 & $0.0086^{*}$ \\
\hline STD NLR & 0.1722 & 0.045 & 3.82 & $0.0002^{*}$ \\
\hline STD NBuB & 0.1731 & 0.045 & 3.82 & $0.0002^{*}$ \\
\hline
\end{tabular}

Student's textbook reading in this disruption era is about the same as a reported study in the USA's printed reading 1990's era. Mokhtari \& Sheorey (1994) reported that university students' academic reading was 9.7 hours per week, and non-academic reading was 4.7 hours per week. Current data on reading habits from USA students are not available, that we could not make any inference on reading habits changing among university students in the disruption era.

In the present study, literature reading was also low, although this leisure reading is an essential factor in determining reading time in the academic textbook. People with good reading habits will read books for leisure in their spare time. Recreational reading improves reading comprehension (Rogiers et al., 2020) and develops higher-order thinking skills (Brozo et al., 2007). PEW survey in 2015 reported that average Americans read 12 books per year, and college students read 17 books per year (https://www.pewresearch). If we added up literature reading data in the present study with the number of academic books read, the number of book titles read by university students would be considered still very low. As students read literature, only one or two titles per year in the present study, significant improvements are required to enhance students' reading habits.

Student's preference for history and biography books over literature needs further study. At present, this may be explained that pleasure reading for science-oriented students is more on biography and literature books. Biography books provide facts of someone's records on his life, in which students are very familiar with their daily works. Literature, however, is more imaginative and fictive. Science-students have a preference for reading facts than fictive materials.

It has been widely known that many students read academic textbooks when they are in the exam period. Therefore, increasing reading practice can be achieved by scheduling more exams. A one-day exam or quiz has been proved to make students reading a book every day (Deslauriers et al., 2011; Aagaard et al., 2014). Monte Carlo Quiz also has been reported to enhance student's reading practice (Fernald, 2004). The online quiz can improve student's reading before class. Eighty per cent of students in the Faculty of Science are reported to read textbooks after the lecturer gives them regular online quizzes before class (Heiner et al., 2014). These methods are up-and-coming to be applied in improving students' reading habits.

Setting an appropriate target of obligatory reading is also crucial in improving student's reading habits. McLean \& Poulshock (2018) compared students' obligatory reading in a foreign language between two groups, with 2500 words target per week and one book target per week. They found that the word-targeted group reads more than the book-targeted group.

Introduction to library visits for first-year students should be done to increase book-reading frequency. The frequency of library visits is strongly linked with high academic achievement. On the other hand, internet use frequency is linked with low academic performance (Oyewole \& Adegoke, 2018). Sustained silent reading (SSR) and library visit positively impact students reading English books (Cho \& Krashen, 2018). 
This finding is somewhat intriguing as reading comprehension is vital for any student at any level (Fernald, 2004). This low reading habit is supported by subsequence data that student's book collection also varies a lot as indicated by a wide standard deviation. This means that few students with good reading habits have many books collection, while many poor-reader students have very few book collections.

This finding, therefore, needs to be elaborated further in future study. Why do the students have such a low reading habit? Does it mean that reading printed materials have been left behind? Can we rely on digital reading material? Do they have chosen suitable scholarly sound science reading materials when they rely more on digital material? When students rely on digital reading materials, do they have sufficient knowledge of basic concepts and principles of sciences? Future studies should elaborate on these questions to have a better perception of students' reading habits.

The present study revealed that students' interests in a textbook (RTB) and information technology (RIT), number of literature reading (NLR), and number of bought books (NBuB) were four critical factors in the duration of students' reading. The four variables should be prioritized into consideration when we are planning to improve students' reading time. This means that book providence in the university library should prioritize two books, i.e. science textbooks and IT books. Literature books should also be accessible for students, although the university may not provide this. These three books are crucial factors to increase students' reading time. The number of books bought by students may indicate the level of students reading habits. Students with good reading habits read more formal books and literature that they bought more books than students with low reading habits.

\section{Conclusions}

Reading habits on printed books of preservice science teacher-student is low. Students spent two hours or less reading textbooks. Literature reading or reading for leisure is also coincidently low, although some students rank literature as their first rank books to read. History or biography books are the most subject students read in printed textbooks. It is, therefore, necessary to improve their reading habits in many ways.

In the classroom, at least we could use two options to increase students' time in reading and providing a quiz before the lecture will motivate students to read textbooks at home. Giving reading assignments is also an important tool to encourage the student to read the textbook. Many studies showed that most students read textbooks only when they are having an exam or quiz.

In the university library, the providence of more sciences and technological information books is very important. Both book subjects were found to have a determination effect on students' duration of reading time. A literature book is also essential to increase reading time duration, but the general public library or students should provide it. Introduction to the library for the first-year students should be encouraged to make more students visiting the library.

Reading habits on e-book and e-journal were not explored in the present study. Future studies should elaborate on this issue, as millennial students are more familiar with electronic reading materials. The study should explore students' ability to distinguished scholarly reading materials from non-scholar ones, sources to get electronic books, reading hours on these electronic reading materials. Such a study is critical to understand students' behaviour in coping with rapid information technology development. 


\section{References}

Aagaard, L., Conner, T.W., \& Skidmore, R.L. (2014) College Textbook Reading Assignments and Class Time Activity. Journal of the Scholarship of Teaching and Learning, 14(3): 132-145.

Alamri, Y., Al-Busaidi, I.S., Bintalib, M.G., \& Abu-Zaid, A. (2020) Understanding of Medical Students about Predatory Journals: A Comparative Study from KSA and New Zealand. Journal of Taibah University Medical Sciences, 15(5): 339343.

AlRyalat, S.A., Farah, R.I., Abukeshek, A., Aldabbas, L., Al-fawair, A., \& Ababneh, O. (2019) Biomedical Researchers and Students Knowledge about Predatory Journals. The Journal of Academic Librarianship, 45(5): 102056.

Annamalai, S., \& Muniandy, B. (2013) Reading Habit and Attitude Among Malaysian Polytechnic Students. International Online Journal of Educational Sciences, 5(1): 3241.

Balan, S., Katenga, J.E., \& Simon, A. (2019) Reading Habits and Their Influence on Academic Achievement Among Students at Asia Pacific International University. Proceedings International Scholars Conference, 7(1): 1490-1516.

Balfour, R.J. (2002) Language Curriculum Development at Tertiary Level in South Africa. Alternation Special Issue on Intercultural Communication, 9(1): 143153.

Bharuthram, S. (2012) Making a Case for the Teaching of Reading Across the Curriculum in Higher Education. South African Journal of Education, 32: 205-214.

Brozo, W.G., Shielm, G., \& Topping, K. 2007. Engagement in Reading: Lessons Learned from Three PISA Countries. Journal of Adolescence and Literacy, 51(4): 304-315.

Cho, K.S., \& Krashen, S. (2018) The Impact of Sustained Silent Reading and a Visit to the Library on Establishing a Reading Habit:
Helpful but not Sufficient. Language and Language Teaching, 7(2): 1-3.

Deslauriers, L., Schelew, E., \& Wieman, C. (2011) Improved Learning in a LargeEnrollment Physics Class. Science, 332: 862-864.

Fernald, P.S. (2004). The Monte Carlo Quiz: Encouraging Punctual Completion and Deep Processing of Assigned Readings. College Teaching, 52(3): 95-99.

Halevi, G., Moed, H., \& Nar-Ilan, J. (2017) Suitability of Google Scholar as a Source of Scientific Information and as a Source of Data for Scientific Evaluation-Review of the Literature. Journal of Informetrics, 11(3): 823-834.

Heiner, C.E., Banet, A.I., \& Wieman, C. (2014) Preparing Students for Class: How to Get $80 \%$ of Students Reading the Textbook Before Class. American Journal of Physics, 82(10): 989-996.

Iftanti, E. (2012). A Survey of the English Reading Habits of EFL Students in Indonesia. Teflin Journal, 23(2): 149-164.

Kurniawan, M., Tanduklangi, A., \& Alberth, A. (2018) A study of EFL Reading Media Preference and Its Correlation to Gender, Learning Style and Achievement. Journal of Language Education and Educational Technology, 3(1).

DOI: $10.33772 /$ jleet.v3i1.6690

Leeder, C. (2019). How College Students Evaluate and Share "Fake News" Stories. Library \& Information Science Research, 41(3): 100967.

Manalu, B.H. (2019) Students' Perception of Digital Texts Reading: A Case Study at the English Education Department of Universitas Kristen Indonesia. Journal of English Teaching, 5(3): 191-203.

Martin-Martin, A., Orduna-Malea, E., Harzing, A.W., \& Lopez-Cozar, E.D. (2017) Can We Use Google Scholar to Identify Highly-Cited Documents? Journal of Infometrics, 11(1): 152-163. 
Martin-Martin, A., Orduna-Malea, E., Thelwal, M., \& Lopez-Cozar, E.D. (2018) Google Scholar, Web of Science, and Scopus: A Systematic Comparison of Citation in 252 Subject Categories. Journal of Infometrics, 12(4): 1160-1177.

McLean, S., \& Poulshock, J. (2018) Increasing Reading Self-efficacy and Reading Amount in EFL Learners with Word-targets. Reading in a Foreign Language, 30(1): 7691.

Mokhtari, K., \& Sheorey, R. (1994). Reading Habits of University ESL Students at Different Levels of English Proficiency \& Education. Journal of Research in Reading, 17(1): 46-61.

Oyewole, T.G., \& Adegoke, J.A. (2018) Effect of the Internet on the Reading Habit and Academic Performance of Under-graduate Students: A Case Study of Bowen University, Iwo. International Journal of Education and Evaluation, 4(4): 88-99.
Rogiers, A., Van Keer, H., \& Merchie, E. (2020) The Profile of the Skilled Reader: An Investigation into the Role of Reading Enjoyment and Student Characteristics. International Journal of Education Research, 99.9 DOI: 10.1016/j.ijer.2019.101512

Sappington, J., Kinsey, K., \& Munsyac, K. (2002) Two Studies of Reading Compliance Among College Students. Teaching of Psychology, 29(4): 272-274.

St Clair-Thompson, H., Graham, A., \& Marsham, S. (2018) Exploring the Reading Practices of Undergraduate Students. Education Inquiry, 9(3): 284298.

Syam, H.M., \& Nurrahmi, F. (2020) "I Don't Know if It is Fake or Real News" How Little Indonesian University Students Understand Social Media Literacy. Jurnal Komunikasi: Malaysian Journal of Communication, 36(2): 92-105. 